\title{
The Effect of Interest and Motivation in Learning Geography Towards Spatial Intelligence of Senior High School Students in Kuantan Singingi Regency
}

\author{
Henki Warsani \\ Graduate Program of Geography Education \\ Universitas Pendidikan Indonesia \\ Bandung, Indonesia \\ Coresponding email: warsanihenki@yahoo.com \\ Mamat Ruhimat \\ Graduate Program of Geography Education \\ Universitas Pendidikan Indonesia \\ Bandung, Indonesia
}

\begin{abstract}
The purpose of this study was to analyze the effect of interest and motivation to learn in learning geography to spatial intelligence. This study used a quantitative approach with survey method. The study populations were 96 students of class XII social program Private senior high school in Kuantan Singingi Regency. Questionnaires were used to collect the data. Data were analyzed using normality test, homogeneity and path analysis by using SPSS version 20.0 . The research results showed that 1) there is a significant effect of the learning interest and the learning motivation in learning geography toward the spatial intelligence; 2) there is a significant effect of the learning interest in learning geography toward the spatial intelligence, and 3) there is a significant effect of the learning motivation in learning geography to spatial intelligence of senior high schools' students in Kuantan Singingi Regency.
\end{abstract}

Keywords-interest; motivation in learning geography; spatial intelligence

\section{INTRODUCTION}

Humans are born with tremendous potentials. One of them is intelligence. Generally speaking, human intelligence is divided into three main parts, i.e. intelligence quotient (IQ), spiritual intelligence (SQ) and emotional intelligence (EQ). Askar (2006, p. 228) states that:

IQ, EQ and SQ are the power of intelligence in humans. All of them centered in the brain that has different orientations and functions, but all three can work together well. IQ (Intelligent quotient) centered on left-side brain functions as logical rational intelligence. EQ (emotional quotient) centered on rightside brain functions as intuitive emotional intelligence. SQ (spiritual quotient) is centered on between both sides which functions as unitive transcendent spiritual. These strengths allow humans to discover the meanings behind all of life experiences.
From the main intelligences of humans described above, Gardner (1983) classifies various intelligences of humans into eight categories, known as Multiple Intelligences. According to Gardner (2003, p. 36), there are eight human intelligences possessed by humans namely linguistic, logical-mathematical, spatial, kinesthetic, musical, interpersonal, intrapersonal, and naturalist intelligence.

One of the intelligences possessed by humans is spatial intelligence. According to Gardner (2003, p. 24), "spatial intelligence is the ability to capture the visual world accurately, recognize and picture it in the mind". Similarly, Suyadi (2006, p. 175) expresses that "spatial intelligence is the ability to see an object in great detail, and then be able to record in the memory of the brain for a long term."

Spatial intelligence of every human will continue to grow to the level of thinking skills called qualified. In a research conducted by Lim (2005, p. 198), he states that "spatial intelligence, regardless of student gender, can be improved by the conduct of fieldtrips designed specifically to afford students opportunities to record, share and co-construct their observations and understandings of the local environments".

One way to develop spatial intelligence is to learn the disciplines associated with spatial or space. Geography is a discipline that studies about the spatial or space. Maryani (2006, p. 5) says that "geography is often identified with the science of space". Likewise, Walmsley and Lewis (1985, p. 7) states that "geography is the study of the earth as a human dwelling and the mirror of man, where and how the surrounding environment utilized by man".

In formal education, geography is one of the subjects taught starting in elementary school (SD) to senior high school (SMA). At the elementary and junior high, geography is integrated with the subjects of history, economics and sociology in the realm of Social Sciences. At the senior high, 
geography becomes an independent subject. However, geography is only being studied in the social program.

Learning geography with the developing content and curriculum tries to develop the students' spatial intelligence. Planting the seeds of spatial or space will be adjusted the school level and the development of students' thinking level so the students can easily understand Earth's surface space according to their ability.

Spatial intelligence gained from learning geography will give the students the ability to make better observations. Students will be able to understand various phenomena on the earth's surface. It means that as a space, earth has phenomena that can be analyzed based on the interaction of biotic components, abiotic and culture contained therein. In addition, students who have spatial intelligence would understand and have knowledge in taking a policy to utilize the space of the earth's surface in order to remain sustainable.

Although spatial intelligence can be developed by learning geography, it does not mean everyone who has studied the geography will have a high spatial intelligence. At the school environment, teachers should be able to excite students to learn geography by paying attention on the students' learning interest and learning motivation. In fact, many experts agree that one of the factors that affect the success of learning geography is the interest of students. Sembiring and Mukhtar (2013, p. 218) state that interests is a tendency to behave in an object-oriented, activity specific experience and a tendency among individuals to one another at the same intensity ".

High learning interest will make students receive the lesson presented by the teacher so the teacher will easily achieve the purpose of learning. In learning geography, Sando (2013, p. 2) states that:

High interest in learning geography will be able to improve learning achievement geography. Due to their high interest in learning geography, it will provide convenience to the students in the learning process, because the students' mind will be concentrated to the problem of the lesson.

Moreover, the motivation is also one thing that can affect the success of learning, especially in learning geography. Cleopatra $(2015$, p. 174) defines motivation to learn as impulse, desire, need to perform certain activities in learning process. Students will learn actively if they have a motivation.

In learning process, motivation to learn is very important. Rafiqah (2013, p. 4) states that motivation has important roles in learning because the motivation will determine the intensity of the students' effort in learning. The higher the motivation of students are, the bigger and stronger the intensity or effort of students will be.

Learning geography experiences a lot of problems in its practice in schools, especially in high school level. It also happens in senior high school in Kuantan Singingi Regency. Based on discussions with several geography teachers in Kuantan Singingi Regency, geography lessons in this regency have slightly different directions with the function and purpose of learning geography that had been set in curriculum
2006. The infelicity can be seen on the insights of the students who have studied geography but still do not understand the spatial aspect that has been learned. In addition, students assume that learning geography is a lesson in which they do memorizing the names of places, rivers, mountains, study a map, the hydrological cycle, the earth's crust and so forth. As a result, the understanding of the patterns and processes of spatial students are still weak and do not correspond with the expected learning objectives of geography.

Learning geography is expected both to connect theoretical knowledge that the students have learned with the factual events which are happening in the field and to connect linkages of each spatial phenomenon to each other because it is the basis for students to understand the spatial problems. In accordance with this case, Prasad $(2015$, p. 2) states that:

Material, object or phenomenon on the earth's surface that stands alone is not very important to geography. It will be essential if the new material or symptoms or phenomena can be connected to other materials. Thus, a geographer candidate is required to sharpen their spatial intelligence.

Looking at the conditions above, it is understood that the case is affected by students' factors of interest and motivation to learn. In the end, the learning interest and learning motivation in learning geography will affect the level of spatial intelligence.

Based on the background that has been stated earlier, there is a need to conduct a research related to the problem. The authors are interested to study the effect of learning interest and learning motivation in learning geography towards spatial intelligence of senior high school students in Kuantan Singingi Regency.

\section{METHOD}

The method of this reseach used a survey. The population of this study was all the students of class XII social class of senior high schools in Kuantan Singingi Regency.

TABLE I. SCHOOL POPULATION AND STUDENTS OF CLASS XII SOCIAL IN KUANTAN SINGINGI REGENCY.

\begin{tabular}{|c|c|c|c|c|}
\hline No & $\begin{array}{c}\text { Region } \\
\text { Divisions }\end{array}$ & Districts & Schools & $\begin{array}{c}\text { Number } \\
\text { of } \\
\text { Student }\end{array}$ \\
\hline \multirow{6}{*}{1} & \multirow{6}{*}{ Region I } & \multirow{3}{*}{$\begin{array}{l}\text { Kuantan } \\
\text { Tengah }\end{array}$} & $\begin{array}{l}\text { SMAN 1 Teluk } \\
\text { Kuantan }\end{array}$ & 207 \\
\hline & & & $\begin{array}{l}\text { SMAN } 2 \text { Teluk } \\
\text { Kuantan }\end{array}$ & 63 \\
\hline & & & SMAN Pintar & 62 \\
\hline & & \multirow{2}{*}{ Sentajo Raya } & $\begin{array}{l}\text { SMAN } 1 \text { Sentajo } \\
\text { Raya }\end{array}$ & 93 \\
\hline & & & $\begin{array}{l}\text { SMAN } 2 \text { Sentajo } \\
\text { Raya }\end{array}$ & 86 \\
\hline & & Benai & SMAN 1 Benai & 233 \\
\hline \multirow{4}{*}{2} & \multirow{4}{*}{ Region II } & \multirow{2}{*}{ Singingi } & $\begin{array}{ll}\text { SMAN } & 1 \\
\text { Singingi } & \\
\end{array}$ & 100 \\
\hline & & & $\begin{array}{ll}\text { SMAN } & 2 \\
\text { Singingi } & \end{array}$ & 130 \\
\hline & & \multirow{2}{*}{ Singingi } & $\begin{array}{ll}\text { SMAN } & 1 \\
\text { Singingi Hilir } & \end{array}$ & 63 \\
\hline & & & $\begin{array}{ll}\text { SMAN } & 2 \\
\text { Singingi Hilir } & \end{array}$ & 40 \\
\hline
\end{tabular}




\begin{tabular}{|c|c|c|c|c|}
\hline & & & $\begin{array}{ll}\text { SMAN } & 3 \\
\text { Singingi Hilir } & \end{array}$ & 60 \\
\hline \multirow{4}{*}{3} & \multirow{4}{*}{ Region III } & \multirow{2}{*}{ Kuantan Mudik } & $\begin{array}{l}\text { SMAN } 1 \\
\text { Kuantan Mudik }\end{array}$ & 166 \\
\hline & & & $\begin{array}{l}\text { SMAN } 2 \\
\text { Kuantan Mudik }\end{array}$ & 56 \\
\hline & & Gunung Toar & $\begin{array}{l}\text { SMAN } 1 \text { Gunung } \\
\text { Toar }\end{array}$ & 117 \\
\hline & & Hulu Kuantan & $\begin{array}{l}\text { SMAN } 1 \text { Hulu } \\
\text { Kuantan }\end{array}$ & 89 \\
\hline \multirow{6}{*}{4} & \multirow{6}{*}{ Region IV } & Kuantan Hilir & $\begin{array}{ll}\text { SMAN } & 1 \\
\text { Kuantan Hilir } & \end{array}$ & 203 \\
\hline & & $\begin{array}{ll}\text { Kuantan Hilir } \\
\text { S. }\end{array}$ & $\begin{array}{l}\text { SMAN } 1 \\
\text { Kuantan Hilir S. }\end{array}$ & 71 \\
\hline & & Pangean & $\begin{array}{ll}\text { SMAN } & 1 \\
\text { Pangean } & \end{array}$ & 66 \\
\hline & & Cerenti & SMAN 1 Cerenti & 203 \\
\hline & & Inuman & SMAN 1 Inuman & 113 \\
\hline & & $\begin{array}{ll}\text { Logas } & \text { Tanah } \\
\text { D. } & \\
\end{array}$ & $\begin{array}{l}\text { SMAN 1 Logas } \\
\text { Tanah D. }\end{array}$ & 30 \\
\hline \multicolumn{4}{|c|}{ Total } & 2.251 \\
\hline
\end{tabular}

To determine the sample schools in Kuantan Singingi Regency, stratified random sampling technique was used, i.e. by classifying senior high schools based on four regions of development. Each region is represented by excel schools and non-excel schools. To determine the number of the samples of high school students in all regions divisions, the writers used Taro Yamane formula in Riduwan and Kuncoro, E. A. (2012, p. 49), as follows:

$n=\frac{N}{N \cdot d^{2}+1}$ (Riduwan and Kuncoro, E. A., 2012, p. 49)

Where:

$\mathrm{n}=$ sample size

$\mathrm{N}=$ population size

$\mathrm{d}^{2}=$ Set Precision

With the total students and an error rate of $10 \%$, then with the formula above sample obtained is as follows:

$n=\frac{2251}{2251(10 \%)^{2}+1}=\frac{2251}{2251(0,1)^{2}+1}=95,74$ students

The calculation of sample of each region division is as follows:

Region I $=\frac{744}{2251} \times 96=31,72=32$ students

Region II $=\frac{423}{2251} \times 96=18,20=18$ students

Region III $=\frac{428}{2251} x 96=18,25=18$ students

Region IV $=\frac{656}{2251} \times 96=27,97=28$ students

Determining the number of samples of each region is by selecting the excel schools and non-excel schools which can be seen in Table 2 .

TABLE II. SAMPLE SCHOOL OF EACH REGION DIVISION

\begin{tabular}{|l|l|l|l|l|}
\hline No & $\begin{array}{c}\text { Region } \\
\text { Sample }\end{array}$ & \multicolumn{1}{|c|}{ School Sample } & $\begin{array}{c}\text { Numbers of } \\
\text { Students }\end{array}$ & Total \\
\hline \multirow{2}{*}{1} & \multirow{2}{*}{ Region I } & $\begin{array}{l}\text { SMAN 1 Teluk } \\
\text { Kuantan }\end{array}$ & 207 & \multirow{2}{*}{270} \\
\cline { 3 - 4 } & $\begin{array}{l}\text { SMAN 2 Teluk } \\
\text { Kuantan }\end{array}$ & 63 & \multirow{2}{*}{163} \\
\hline 2 & \multirow{2}{*}{ Region II } & SMAN 1 Singingi & 100 & \\
\cline { 3 - 4 } & SMAN 1 Singingi & 63 & \multicolumn{2}{|c}{} \\
\hline
\end{tabular}

\begin{tabular}{|l|l|l|l|l|}
\hline & & Hilir & & \\
\hline \multirow{3}{*}{3} & \multirow{2}{*}{ Region III } & $\begin{array}{l}\text { SMAN 1 Kuantan } \\
\text { Mudik }\end{array}$ & 166 & \multirow{2}{*}{283} \\
\cline { 3 - 4 } & $\begin{array}{l}\text { SMAN 1 Gunung } \\
\text { Toar }\end{array}$ & 117 & \multirow{2}{*}{269} \\
\hline \multirow{2}{*}{4} & \multirow{2}{*}{ Region IV } & $\begin{array}{l}\text { SMAN I Kuantan } \\
\text { Hilir }\end{array}$ & 203 & 66 \\
\cline { 3 - 4 } & SMAN 1 Pangean & 66 & \multicolumn{2}{|c|}{ Source: Research Data Analysis, 2016 } \\
\hline
\end{tabular}

In sampling the students from each excel schools and nonexcel schools selected, the formulation by Singarimbun and Effendi (1991, p. 89) was used.

Where:

$$
n k=\frac{P k}{P} \times n
$$

$\mathrm{n}_{\mathrm{k}}=$ The number of sample component in the number of component

$\mathrm{p}_{\mathrm{k}}=$ The number of population in the group

The number of respondent sample in excel schools and non-excel schools based on the formula above can be seen in the following table 3 .

TABLE III. SAMPLE CALCULATION OF EACH SCHOOL

\begin{tabular}{|c|c|c|c|}
\hline \multirow{2}{*}{ Region } & \multirow{2}{*}{ School } & \multicolumn{2}{|c|}{ School Sample Calculation } \\
\hline & & Excel & Non-Excel \\
\hline \multirow{2}{*}{ Region I } & $\begin{array}{l}\text { SMAN } 1 \text { Teluk } \\
\text { Kuantan }\end{array}$ & $\begin{array}{c}\frac{207}{270} \times 32=25 \\
\text { students }\end{array}$ & \\
\hline & $\begin{array}{l}\text { SMAN } 2 \text { Teluk } \\
\text { Kuantan }\end{array}$ & & $\begin{array}{c}\frac{32}{270} \times 32=7 \\
\text { students }\end{array}$ \\
\hline \multirow{2}{*}{ Region II } & SMAN 1 Singingi & $\begin{array}{c}\frac{100}{163} \times 18=11 \\
\text { students }\end{array}$ & \\
\hline & $\begin{array}{l}\text { SMAN } 1 \text { Singingi } \\
\text { Hilir }\end{array}$ & & $\begin{array}{c}\frac{63}{163} \times 18=7 \\
\text { students }\end{array}$ \\
\hline \multirow{2}{*}{ Region III } & $\begin{array}{l}\text { SMAN } 1 \text { Kuantan } \\
\text { Mudik }\end{array}$ & $\begin{array}{c}\frac{166}{283} \times 18=11 \\
\text { students }\end{array}$ & \\
\hline & $\begin{array}{l}\text { SMAN } 1 \text { Gunung } \\
\text { Toar }\end{array}$ & & $\begin{array}{c}\frac{117}{283} \times 18=7 \\
\text { students }\end{array}$ \\
\hline \multirow[b]{2}{*}{ Region IV } & $\begin{array}{l}\text { SMAN } 1 \text { Kuantan } \\
\text { Hilir }\end{array}$ & $\begin{array}{c}\frac{203}{269} \times 28=21 \\
\text { students }\end{array}$ & \\
\hline & SMAN 1 Pangean & & $\begin{array}{l}\frac{66}{269} \times 28= \\
7 \text { students }\end{array}$ \\
\hline
\end{tabular}

Furthermore, the sampling of students in each school is determined by simple random sampling. Analyzing the causal relationship between independent variables and the dependent variable in this research is done by using statistical procedures path analysis. The use of path analysis in this research was aimed to see how much effect the independent variables on the dependent variable.

\section{FINDING AND DISCUSSION}

\section{A. Research Findings}

Interest and motivation in learning geography are two things that will not be separated from the learning process. Interest is the desire or tendency to concentrate, sense of loving, interest in learning activity, which is demonstrated by the enthusiasm in learning, active learning and realizing the importance of the learning activities while the motivation, is a 
boost that can move the students to learn geography in order to learn geography goal can be achieved. Strong motivation in learning geography will be able to encourage students to be more active in learning geography, so the targeted goals will be easily achieved.

Interpretation of the interest variable in learning geography was done by a few indicator points covering a sense of excitement, interest, attention and involvement (Sando, 2013, p. 7-8). On the other hand, the interpretation of the motivation variable in learning geography was conducted by outlining some points of indicators covering, have a high passion to learn geography, energetic, have a curiosity to study geography, is able to find own way when the teacher asks students to do something, particularly a sense of confidence, has a higher concentration, consider the difficulty as a challenge to be overcome, have the patience and highly motivated (Asrori, 2009, p. 184).

The spatial intelligence variable interpretation was done by outlining some of the indicators of spatial intelligence which are comparison, aura, region, transition, analogy, hierarchy, pattern and association (Association of American Geographer in Sugiyanto, 2013, p. 147-148).

The hypothesis of this research is the interest and motivation in learning geography simultaneously affects the spatial intelligence. Path coefficient values obtained from the correlation between variables using SPSS version 20 can be seen in Table 4.

TABLE IV. RESULT OF F TEST

\begin{tabular}{|c|l|l|l|l|l|l|}
\hline \multicolumn{1}{|c|}{ Model } & \multicolumn{1}{|c|}{$\begin{array}{c}\text { Sum of } \\
\text { Squares }\end{array}$} & \multicolumn{1}{|c|}{ Df } & $\begin{array}{c}\text { Mean } \\
\text { Square }\end{array}$ & \multicolumn{1}{|c|}{ F } & Sig. \\
\hline \multirow{2}{*}{$\begin{array}{l}\text { Regression } \\
\text { Residual }\end{array}$} & 4149.530 & 2 & 2074.765 & 26.455 & $.000^{\mathrm{b}}$ \\
& 7293.561 & 93 & 78.425 & & \\
\hline
\end{tabular}

a. Dependent Variable: SPATIAL_INTELLIGENCE

b. Predictors: (Constant), MOTIVATION, INTEREST

Source: Research Findings, 2016

Research $\mathrm{a}$ is 0.05 , so the value of the $\mathrm{T}_{\text {table }}$ is 3.8. Based on Table $4, \mathrm{~F}_{\text {count }}=26.455$ and $\mathrm{F}_{\text {table }}=3.09$, because $\mathrm{F}_{\text {count }}>$ $\mathrm{F}_{\text {table, }}$, then interest $\left(\mathrm{X}_{1}\right)$ and learning motivation in learning geography $\left(\mathrm{X}_{2}\right)$ together affects the spatial intelligence $(\mathrm{Y})$. The magnitude of the simultaneous effect of interest and motivation in learning geography to students' spatial intelligence can be seen in Table 5 below:

TABLE V. OEFFICIENT DETERMINATION INTERESTS $\left(\mathrm{X}_{1}\right)$ AND MOTIVATION IN LEARNING GEOGRAPHY $\left(\mathrm{X}_{2}\right)$ TO SPATIAL INTELLIGENCE

\begin{tabular}{|l|l|l|l|l|}
\hline Model & \multicolumn{1}{|c|}{ R } & R Square & \multicolumn{1}{|c|}{$\begin{array}{c}\text { Adjusted R } \\
\text { Square }\end{array}$} & $\begin{array}{c}\text { Std. Error of the } \\
\text { Estimate }\end{array}$ \\
\hline 1 & $.602^{\mathrm{a}}$ & .363 & .349 & 8.85581 \\
\hline
\end{tabular}

Source: Research Findings, 2016

The results of the calculations in table 5 above shows that the coefficient of determination interest and motivation in learning geography simultaneously affects to spatial intelligence at 0.363 . In addition, there are other effects of other variables obtained by calculating using the following formula:

$$
\begin{aligned}
& \mathrm{P}_{\mathrm{Y \epsilon}}=\sqrt{1-R^{2}{ }_{\gamma \times 1 \times 2}} \\
& \mathrm{P}_{\mathrm{Y \epsilon}}=\sqrt{1-0.363} \\
& \mathrm{P}_{\mathrm{Y \epsilon}}=0.637
\end{aligned}
$$

The number of path coefficients for other variables which are not included in the specification of this research is 0637 , so the path coefficient value based on a calculation can be seen in Table 6 below:

TABLE VI. RESULT OF PATH COEFFICIENT VALUE OF INTEREST AND MOTIVATION IN LEARNING GEOGRAPHY TOWARDS SPATIAL INTELLIGENCE

\begin{tabular}{|c|l|l|l|l|l|l|}
\hline \multicolumn{2}{|c|}{ Model } & \multicolumn{2}{|c|}{$\begin{array}{c}\text { Unstandardized } \\
\text { Coefficients }\end{array}$} & $\begin{array}{c}\text { Standardized } \\
\text { Coefficients }\end{array}$ & \multirow{2}{*}{ T } & \multirow{2}{*}{ Sig. } \\
\cline { 3 - 6 } \multicolumn{2}{|c|}{} & $\boldsymbol{B}$ & Std. Error & Beta & & \\
\hline \multirow{3}{*}{1} & (Constant) & -16.817 & 7.407 & & - & .025 \\
\cline { 2 - 7 } & INTEREST & .541 & .107 & .465 & 5.036 & .000 \\
\cline { 2 - 7 } & MOTIVATION & .177 & .072 & .228 & 2.473 & .015 \\
\hline
\end{tabular}

a. Dependent Variable: SPATIAL_INTELLIGENCE

Source: Research Findings, 2016

From the calculation results in table 6 , it can be obtained that the path coefficients for interest in learning geography $\left(\mathrm{P}_{\mathrm{Yx} 1}\right)$ is 0465 , and the motivation in learning geography $\left(\mathrm{P}_{\mathrm{Yx} 2}\right)$ is 0.228 . Thus, the hypothesis testing was obtained $\mathrm{R}^{2}=0.364$ and $F=26455(p=0.000)$ has a significant effect of interest and motivation in learning geography to spatial intelligence.

The coefficients equation path in explaining the effect of the interest and motivation in learning geography to spatial intelligence is expressed as follows:

$$
\mathrm{Y}=0.465 \mathrm{X} 1+0.228 \mathrm{X} 2+0.637_{\mathrm{e} 1}
$$

Structural model of interest and motivation effect in learning geography to spatial intelligence can be described in Figure 1 below:

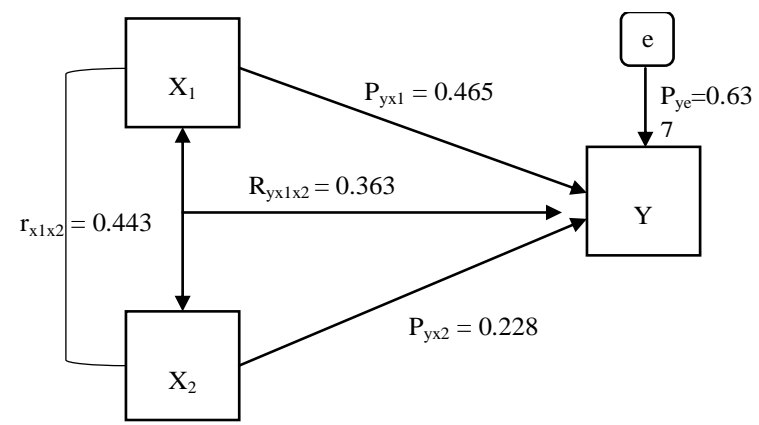

Fig. 1. Diagram Line Structural Equation Modeling Effect of Interest and Motivation in Learning Geography towards Spatial Intelligence

Hypothesis testing was done in two stages: stage of simultaneous hypothesis testing and partial testing to determine the significance of the effect of interest variable in learning geography to spatial intelligence and effect of motivation in learning geography to spatial intelligence. Value of $\mathrm{a}=0.05$, therefore $\mathrm{t}$ table is $\mathrm{t}_{(0.95 ; 96)}=1,661$. Resultof partial test is presented in the table 4:10 below: 
TABLE VII. RESUlt OF PARTIAL TEST

\begin{tabular}{|l|l|l|l|l|l|l|}
\hline No & Hypotheses & $\begin{array}{c}\text { Path } \\
\text { Coefficients }\end{array}$ & $\mathbf{t}_{\text {count }}$ & $\mathbf{t}_{\text {table }}$ & Decision & $\begin{array}{c}\text { Statistical } \\
\text { Conclusion }\end{array}$ \\
\hline 1 & $\begin{array}{l}\text { Interest in } \\
\text { leaning } \\
\text { geography } \\
\text { towards } \\
\text { spatial } \\
\text { intelligence }\end{array}$ & 0.465 & 5.036 & 1.661 & $\begin{array}{l}\text { Ho } \\
\text { rejected }\end{array}$ & Significant \\
\hline 2 & $\begin{array}{l}\text { Motivation } \\
\text { in learning } \\
\text { geography } \\
\text { towards } \\
\text { spatial } \\
\text { intelligence. }\end{array}$ & 0.228 & 2.473 & 1.661 & $\begin{array}{l}\text { Ho } \\
\text { rejected }\end{array}$ & Significant \\
\hline
\end{tabular}

From table 7 above, it can be seen that partially with the growing interest in learning geography $\left(\mathrm{X}_{1}\right)$, it has positive effect on spatial intelligence, and motivation in learning geography $\left(\mathrm{X}_{2}\right)$ will have positive effect to spatial intelligence (Y).

\section{B. Discussion}

Based on the results of data analysis and research, it can be analyzed that the interest and motivation in learning geography have positive effects on students' spatial intelligence. The coefficient determination of interest and motivation in learning geography simultaneously effect students' spatial intelligence by 0363 , or by $36.3 \%$, so that it can be seen that there are other factors that are not described in this research that affect students' spatial intelligence. The magnitude of these other factors is $63.7 \%$.

Interest and motivation in learning geography is a psychological factor that can affect the students to learn geography. Therefore, interest and motivation in learning geography are associated with psychiatric elements to encourage or induce behavioral study. Their interest and motivation in geography high learning will make the learning behavior of students will also be high. High learning behavior is shown by their high participation in learning process, so it will affect the level of students' spatial intelligence.

Meanwhile, the partial effect of learning interest in learning geography to spatial intelligence showed that the obtained $t_{\text {count }}=5036$ and $t_{\text {table }}=1,661$, because of $t_{\text {count }}>t_{\text {table, }}$, therefore the independent variable interest in learning geography $\left(\mathrm{X}_{1}\right)$ has positive effect on students' spatial intelligence (Y). The magnitude of the effect of learning interest in learning geography to students' spatial intelligence is at $21.62 \%$. From these results, it indicates that the higher interest in learning geography, the higher the level of students' spatial intelligence is. This is in line with what Sando (2013, p. 2) states, that the interest in learning geography high will be able to improve students' learning achievementdue to their high interest in learning geography, it will provide convenience to themselves in the learning process because the students' mind will concentrate on the lesson.

Based on these opinions, these research findings are supported by a research conducted by Sando (2013 p. 6) about the relationship between the learning environment and interest in learning and the learning achievement geography class XI social class of SMAN 1 Belalau in which he found that there is a positive and significant correlation between interest in learning and students' academic achievement. In addition, this research is also supported by a research conducted by Novitasari, Haryono and Miswar (2003 p. 6) about the relationship of interest with students' achievement in geography in SMA Utama Metro which states that the higher interest in learning geography there is, then the higher the students' achievement tends to be, and vice versa.

Sagala, S. (2012: 57) argues that one of the conditions where the students can successfully learn is to cultivate a passion for the subject. When the students are interested in studying geography, attention and concentration during the study will be poured for geography learning process according to their interests so spatial intelligence will also increase.

There are many things that can be done to increase interest in learning geography. One of them is that a teacher must be able to make geography learning process become more interesting and fun. When the students feel learning geography interesting and fun, then the students' interest in learning geography will emerge by itself.

Moreover, motivation in learning geography also affects spatial intelligence. From the analysis, the results showed that $t_{\text {count }}=2,473$ and $t_{\text {table }}=1,661$, because $t_{\text {count }}>t_{\text {table }}$, therefore the independent interest in learning geography variable $\left(\mathrm{X}_{2}\right)$ has positive effect on students' spatial intelligence (Y). The magnitude of the effect of motivation in learning geography to students' spatial intelligence is at 5:19\%. The results of this analysis show that the motivation in learning geography affect the spatial intelligence of the senior high school students in Kuantan Singingi Regency, but the effect is not significant.

In geography learning activities, their motivation will encourage students to consciously learning activities. Motivation will move students to perform learning activities with full awareness in order to achieve the learning objectives. Motivation in learning geography is a catalyst, driving and steering actions to succeed in the learning process. According to Uno, H. B. (2006, p 3) in learning, motivation is necessary, because someone who does not have the motivation to learn will not be possible to participate learning activities.

Motivation in learning geography is also a driving force to conduct learning activities. As a driving force, motivation will affect the attitude towards the learning process geography. This will affect the achievement of students' spatial intelligence. Uno, H. B. (2006, p. 3) states that motivation in learning can serve as a driving force to achieve learning achievement.

The motivation functions as a direction to the learning process. Motivation will make students to have a clear direction and purpose in conducting the learning process that is to achieve satisfying spatial intelligence. Motivation directs the learning process so the learning activities become more effective. The effective learning process supports the achievement of students' spatial intelligence to the maximum. According to Winardi (2001, p. 33), motivation is a psychological process that causes the activity of which is directed at a particular destination. It means that the 
motivation in learning geography will direct students to achieve spatial intelligence.

This research finding prove that the motivation in learning geography affect the students' spatial intelligence, which means the better the learning motivation in learning geography is, the better the students' spatial intelligence will be. This is supported by research conducted by Rafiqah (2013, p. 8). She states that motivation has a significant effect on learning achievement among students of XI social class of SMAN 2 Metro in the academic year 2012/2013. Other studies conducted by Suparmi, Sarwono and Rindarjono (2015, p. 27) in class X SMA Negeri 9 Surakarta in 2013 showed that a high learning motivation classification is more effective than low learning motivation classification in influencing the outcomes of learning geography.

Based on the results of the two researchers described above, it shows that the higher the motivation of the students is, the higher the achievement and learning outcomes of students will be. Therefore, those researches findings support the findings of this study that found that the higher the motivation to learn in learning geography is, the higher the level of students' spatial intelligence will be. A teacher is expected to be able to motivate his students to learn for students' spatial intelligence to develop in accordance with the stages of development because spatial intelligence is very important for students in their everyday life. By having better spatial intelligence, students will be able to understand every phenomenon that occurs in the earth's surface.

From this research finding, it can be seen that the two factors that affects the spatial intelligence are interest and motivation to learn geography of the students at senior high schools in Kuantan Singingi Regency. The most influential factor on spatial intelligence is the learning interest in learning geography which is at $21.62 \%$, while the rest is affected by the motivation in learning geography and other factors that are not described in this research like good family environment and school environment, teacher competence and so forth.

\section{CONCLUSIONS AND SUGGESTIONS}

Interest and motivation in learning geography simultaneously have positive effects on students' spatial intelligence. This shows that the students' spatial intelligence will be higher if interest and motivation in learning geography also higher. The interest and motivation in learning geography will make the students' learning behavior high. High learning behavior is shown by their high participation in any learning process, so it will affect the level of students' spatial intelligence. Learning interest in learning geography will make the students interested to learn geography. With a sense of love, happy and feel interested in learning geography, students' spatial intelligence will be able to develop properly. Meanwhile, motivation in learning geography will lead students to act or to perform the learning activities to achieve specific objectives that are to improve students' spatial intelligence.

\section{ACKNOWLEDGMENT}

The writer would like to express his greatest gratitude to beloved parents, Mr. Warman, S.Pd and Mrs. Lasniar and also his sisters, Mailul Hayati, Tengku Maulana, and Humaira Salsabilla who always give their support to the writer. The writer would also like to express the gratitude to Head of Program of Geography Education, Universitas Pendidikan Indonesia. At last, the writer thanks the head of Service and License Center, the principals, and the students of senior high schools in Kuantan Singingi Regency.

\section{REFERENCES}

[1] A. Sando, "Hubungan Antara Lingkungan Belajar dan Minat Belajar dengan Prestasi Belajar Geografi," Jurnal Penelitian Geografi vol. 1 : 6 2013, pp. 2, 6, 7-8.

[2] Askar, "Potensi dan Kekuatan Kecerdasan pada Manusia (IQ, EQ dan SQ) dan Kaitannya dengan Wahyu," Jurnal Hunafa vol. 3 : 3, September 2006 p. 228.

[3] Central Bureau of Statistics, Kuantan Singingi Regency in numbers. Teluk Kuantan: CBS, 2015.

[4] D. J. Walmsley, and G. J. Lewis, Human Geography, Behavioral Approaches. London: Longman, 1984

[5] D. Novitasari, E. Haryono and D. Miswar, "Hubungan Minat dengan Prestasi Belajar Siswa pada Mata Pelajaran Geografi di SMA Utama Wacana Metro," Jurnal Penelitian Geografi vol. 1 : 6, 2013, pp. 6.

[6] E. Maryani, Geografi dalam Perspektif Keilmuan dan Pendidikan di Persekolahan. Published in the book "Ilmu Pendidikan", 2006, author Mohamad Ali (ed), Bandung, 2006.

[7] H. B. Uno, Perencanaan Pembelajaran. Jakarta: Bumi Aksara, 2006.

[8] H. Gardner, "Kecerdasan Majemuk: Teori dalam Praktek," Transl. by Arvin Saputra. Batam: Interaksara, 2003.

[9] J. R. Prasad, "Realita Geografer; Dari Kecerdasan Spatial Menuju Kecintaan Kepada Geografi," available at http://dokumen.tips/documents/kecerdasan-Spatial-menuju-kecerdasangeografi.html, 2015.

[10] K.Y.T. Lim, "Augmenting Spatial Intelligence in the Geography Classroom," Journal International Research in Geographical and Environment Education vol. 14 : 3, 2005, pp 198.

[11] M. Asrori, Psikologi Pembelajaran. Bandung: CV. Wacana Prima, 2009.

[12] M. Cleopatra, "Pengaruh Gaya Hidup dan Motivasi Belajar Terhadap Prestasi Belajar Matematika," Jurnal Formatif, vol 5 : 2, 2015, pp. 174.

[13] M. Rafiqah, "Pengaruh Motivasi Belajar Siswa Terhadap Prestasi Belajar Siswa," Jurnal Bimbingan Konseling, Vol. 2 : 2, 2013. pp. 4-8.

[14] M. Singarimbun, S. Effendi, Metode Penelitian Survei. Jakarta: LP3ES, 1991.

[15] R. Br. Sembiring, Mukhtar, "Strategi Pembelajaran dan Minat Belajar Terhadap Hasil Belajar Matematika," Jurnal Teknologi Pendidikan, vol. $6: 1$, April 2013, pp. 218.

[16] Riduwan and E. A. Kuncoro, Cara Mengggunakan dan Memakai Path Analysis (Analisis Jalur). Bandung: Alfabeta, 2012

[17] S. Sagala, Konsep dan Makna Pembelajaran Untuk Membantu Memecahkan Problematika Belajar dan Mengajar. Bandung: Alfabeta, 2012

[18] Sugiyanto, "Penerapan SIG (Sistem Informasi Geografi) Sebagai Model Pembelajaran Untuk Pengembangan Kecakapan Berfikir Keruangan Di SMU (Sekolah Menengah Umum)," Prosing Pertemuan Ilmiah Tahunan XVI Ikatan Geograf Indonesia. Banjarmasin 2-3 November 2013.

[19] Suparmi, Sarwono and M. G. Rindarjono, "Pengaruh Model Pembelajaran dan Motivasi Belajar Geografi Terhadap Hasil Belajar Geografi Pada Materi Sejarah Pembentukan Bumi dan Jagat Raya Siswa Kelas X SMA Negeri 8 Surakarta Tahun 2013,” Jurnal GeoEco Vol. 1 : 1, Januari 2015, pp. 27.

[20] Suyadi, Kiat Jitu dalam Mendidik Anak. Jakarta: Penerbit Mahkota, 2006.

[21] Winardi, Motivasi dan Pemotivasian dalam Manajemen. Jakarta: Raja Grafindo Persada, 2001. 